Although Professor Szamuely's narrative ends with 1893, it is very contemporary, even monitory, in spirit. By its nature controversial and endlessly debatable, this book will nonetheless stand as a worthy memorial not only to the author's intellectual powers but also to his intense concern for the future of the Western tradition.

\author{
Nathan Smith \\ Washington College
}

\title{
DIE STAATSBEDINGTE GESELLSCHAFT IM MOSKAUER REICH: ZAR UND ZEMLJA IN DER ALTRUSSISCHEN HERRSCHAFTSVER- FASSUNG, 1613-1689. By Hans-Joachim Torke. Studies in East European History, vol. 17. Leiden: E. J. Brill, 1974. x, 328 pp. 80 Dglds.
}

In his ambitious and important new book, Hans-Joachim Torke studies the interaction of government and society in seventeenth-century Russia. The focus of his work is what he calls the "zemlia"- the politically active elements of society which remained, to some extent, outside the sphere of state activity. Although Torke admits that the term "zemlia" is difficult to define sociologically, it is clear that it includes the urban population and probably also those noblemen who were not active in state service. Politically disenfranchised groups, such as the serfs, obviously played no role in the "zemlia."

Torke divides his study of the "zemlia" in the seventeenth century into chapters on elected local administrative bodies, the collective petitions of the merchants and the gentry, the zemskii sobors, and urban revolts. His ordering of topics is deliberate. He argues that the nonstate sectors of Russian society articulated their desires first-in the latter half of the sixteenth century-through the elected gubnyi and zemskii institutions, then, in succession, in the zemskii sobors during the Time of Troubles and the years immediately following this period, and finally in the collective petitions of the $1620 \mathrm{~s}$ and 1630s. The first and greatest urban revolt broke out in 1648 largely because the government had ignored the grievances of the petitioners.

As Torke points out, the power of the tsarist government overshadowed the "zcmlia" at the best of times. The gubnyi and zemskii elders, from the beginning, had to perform burdensome administrative tasks for the state. Thus, the difficulty of finding men to fill these offices is not surprising. Moreover, in more general terms, the position of Russian nobles and merchants was far weaker than that of their central European counterparts, because they not only had no corporate institutions or rights but, throughout the Muscovite period, they showed little awareness of a need to win recognition of their rights and privileges as an estate. When they expressed themselves at all, they made concrete demands for relief from immediate grievances. Yet, Torke argues, we must not exaggerate the weakness of the groups that made up the "zemlia." The very existence of the elected local officials testifies to the limits of the effective power of the central administration: the state was forced to depend on the "zemlia" to perform some of its essential functions. Moreover, in moments of crisis, the nonstate sectors of society could force the tsar's government to meet its demands.

Torke suggests that it was precisely the strength of the "zemlia" that was its undoing. In the crisis of 1648 , the government rightly saw the first important signs of political cooperation between the service gentry (who were still the core 
of the army) and the urban population, and for fear that such cooperation might threaten its power, the government dispensed with zemskii sobors and discouraged collective petitions. Of course, the local elected officials continued to function and, in fact, the government actually gave the elders new responsibilities in the late 1670 s. But as the century passed, the central bureaucracy brought the local elders under increasingly strict tutelage, and, by about 1680 , the "zemlia" was virtually silent. Peter I had only to give a borrowed European dress to the absolutism that had already come into being in the second half of the seventeenth century.

This brief and, of necessity, oversimplified summary of Torke's central contentions gives only a hint of the value of his work. Each individual chapter is an excellent monograph in its own right. His discussion of the history and significance of the zemskii sobor is particularly masterful.

Torke's work displays some of the strengths and weaknesses of Verfassungsgeschichte. He pays careful attention to the legal norms and cultural assumptions of the period and is extremely sensitive to the meaning and overtones of historical terminology. At the same time, his work occasionally presents a different semantic problem-a tendency to reify his own analytical constructs, especially "zemlia" itself. It is sometimes hard to tell which social groups made up the "zemlia." For example, at several crucial points in his argument, "zemlia" seems to shrink and become just a fancy word for the merchants or the urban population.

Torke's excellent book makes important contributions not only to the study of seventeenth-century Russian institutions and society, but also to the continuing debate on Russia's place in the scheme of world history. From his analysis of the "zemlia," Torke concludes, with characteristic clarity and common sense, that seventeenth-century Russia was neither an absolute monarchy of the European type nor an oriental despotism: there were no estates with corporate rights that could serve to counterbalance royal power, and at the same time, the tsar-unlike the oriental despot-was limited by Christian moral imperatives and customary laws on inheritance. At that time, the nonstate sectors of Russian society were comparatively weak and inarticulate, but they were nevertheless indispensable to the administration, and, on occasion, they were capable of exerting decisive pressure on the government. This society-closely tied to the state but far from supine before it-is labeled "state conditioned" (staatsbedingte) by Torke, and is, therefore, placed somewhere between Western Europe and Asia on the historical spectrum.

ROBert O. Crummey

University of California, Davis

RUSLANDS ALLIANCEPOLITIK EFTER FREDEN I NYSTAD: EN STUDIE I DET SLESVIGSKE RESTITUTIONSSP $\emptyset$ RGSMAL INDTIL 1732. By Hans Bagger. Copenhagen University, Institute of Slavonic Studies, Study Series, vol. 4. Copenhagen: Rosenkilde and Bagger, 1974. 304 pp. English summary. Dkr. 60, paper.

Based on extensive archival studies in the USSR, Austria, Denmark, and Holstein, this ambitious study is important not only for its analysis of the motivation of Russian foreign policy during the mid-1720s, but also for its new interpretation of the genesis of the Supreme Privy Council in 1726. Unencumbered by previous 